\title{
Cytoskeletal changes induced by excess extracellular matrix impair endothelial cell replication
}

\author{
F. Podestá ${ }^{1}$, T. R oth ${ }^{1}$, F. Ferrara ${ }^{2}$, E . Cagliero ${ }^{1}$, M . L orenzi ${ }^{1}$ \\ ${ }^{1}$ Schepens Eye Research Institute and Department of Ophthalmology, Harvard Medical School, Boston, Massachussets, USA \\ ${ }^{2}$ Department of Laboratory Medicine, Scientific Institute S. Raffaele, Milano, Italy
}

Summary Thickening of basement membranes is an early and characteristic feature of diabetic vessels, but its consequences on the properties of vascular cells remain undefined. We investigated whether and how excess extracellular matrix (ECM) alters the replication of vascular endothelial cells in vitro. To test the effects of endogenous excess matrix, human umbilical vein endothelial cells (HUVEC) were plated on ECM produced under culture conditions (high ambient glucose) that increase ECM synthesis. Four of six HUVEC isolates plated on such ECM yielded a lower cell number $(68 \pm 18 \%)$ than cells plated on control ECM. Growth inhibition was observed in HUVEC cultured on elevated concentrations $(10$ and $50 \mu \mathrm{g} / \mathrm{ml})$ of exogenous fibronectin, when compared with HUVEC plated on tissue culture plastic or $0.25,1.0$, and $5.0 \mu \mathrm{g} / \mathrm{ml}$ fibronectin; the decreased replication was attributable to delayed transit through the $\mathrm{G}_{1}$ phase of the cell cycle. HUVEC grown on both 1 and $10 \mu \mathrm{g} / \mathrm{ml}$ fibronectin exhibited a modest upregulation of the fibronectin- specific integrin receptor $\alpha 5 \beta 1$, and increased attachment to fibronectin substratum. However, unique to the HUVEC plated on growth-inhibitory concentrations of fibronectin was a redistribution in situ of integrins and vinculin to form more numerous focal adhesions, and an increased polymerization of cytoskeletal actin to form stress fibers. Concentrations $(0.01 \mu \mathrm{g} /$ $\mathrm{ml}$ ) of cytochalasin D intended to prevent excess actin polymerization prevented the growth inhibition. Thus, excess ECM hampers endothelial cell replication in vitro through increased cell-ECM adhesion and attendant cytoskeletal rearrangements. These phenotypic changes provide probes to test whether cell-ECM interactions are altered in diabetic vessels in a direction that may compromise orderly endothelial cell renewal and its antithrombogenic function. [Diabetologia (1997) 40: 879-886]

Keywords Endothelial cells, fibronectin, focal adhesion, F-actin, cytochalasin D, proliferation, diabetic microangiopathy.
Most studies addressing how cellular phenotypes are affected by the extracellular matrix (ECM) have contrasted cellular responses to different ECM molecules or combinations of molecules, and provided paradigms for interpreting histogenesis, differentiated

Received: 14 January 1997 and in revised form: 2 April 1997

Corresponding author: M. Lorenzi, M.D., Schepens Eye Research Institute, 20 Staniford Street, Boston, MA, 02114, USA A bbreviations: ECM, Extracellular matrix; F-actin, filamentous actin; TGF- $\beta$, transforming growth factor- $\beta$; HUVEC, human umbilical vein endothelial cells; PBS, phosphate buffered saline; BSA, bovine serum albumin. function, and tissue repair [1-3]. We are interested in the possibility that learning whether and how cellular phenotypes are also affected by quantitative changes in the underlying or surrounding ECM may provide paradigms for interpreting pathologies characterized by excess ECM accumulation. One such pathology is diabetic microangiopathy. The process, initiated by the metabolic abnormalities of diabetes, is hallmarked by increased thickness of vascular basement membranes and excess ECM accumulation in the renal mesangium, and leads eventually to microvascular obliteration and the well known clinical sequelae of diabetes [4]. Mesangial expansion is thought to play a pathogenetic role in the loss of glomerular 
function by encroaching on the subendothelial space of the glomerulus and compromising the capillary lumen [5]. On the other hand, any primary or ancillary role of basement membrane thickening in the causation of consequential vascular lesions remains conjectural.

In vitro studies indicate that some important cellular functions are hampered by excess ECM. The speed of migration of smooth muscle cells is optimal at intermediate strength of attachment to the ECM, and excess attachment as induced by large concentrations of fibronectin or type IV collagen reduces the speed of migration [6]. Increasing concentrations of fibronectin also decrease endothelial cell migration and replication [7], and complex ECM deposited in excess by endothelial cells exposed to transforming growth factor- $\beta$ (TGF- $\beta$ ) or retinoids does not sustain the same rate of endothelial cell proliferation as ECM isolated from control cultures $[8,9]$.

Although the turnover of vascular endothelium, in particular in retinal microvessels, is normally low [10], it may be increased in diabetes since in this condition retinal microvascular cells undergo accelerated death, probably by apoptosis [11]. Interferences with efficient endothelial cell replication could thus compromise prompt restoration of a non-thrombogenic vascular lining and lead to vascular occlusions. We performed this study to further evaluate the effect of excess ECM on endothelial cell proliferation and to identify the molecular changes that underlie the growth - inhibitory properties.

\section{Materials and methods}

Cell culture and proliferation on various E CM s. HUVEC were isolated and cultured as previously described [12]. Each isolate was derived from an individual umbilical vein, and used for experiments at the first or second passage. Cells were cultured in medium 199 (Gibco Laboratories, Grand Island, N. Y., USA) supplemented with $14 \%$ heat-inactivated pooled human serum, $20 \mu \mathrm{g} / \mathrm{ml}$ endothelial cell growth supplement (Collaborative Biomedical Products, Bedford, Mass., USA), $90 \mu \mathrm{g} / \mathrm{ml}$ heparin (Gibco), $2 \mathrm{mmol} / \mathrm{l}$ glutamine, and $17.5 \mathrm{mmol} / \mathrm{l}$ Hepes buffer. To test the effect of excess endogenous ECM on endothelial cell proliferation, ECM was prepared from cultures of HUVEC that had been exposed to high $(30 \mathrm{mmol} / \mathrm{l})$ or physiological $(5 \mathrm{mmol} / \mathrm{l})$ glucose concentrations for 12 days. Cells were detached by treatment with $1 \mathrm{mmol} / \mathrm{l}$ EDTA in phosphate buffered saline (PBS) during rotation at approximately $160 \mathrm{rev} / \mathrm{min}$ on an orbital shaker for $30 \mathrm{~min}$ at room temperature, and new HUVEC were plated $\left(6 \times 10^{4}\right.$ cells/dish $)$ on the cell-free matrix washed with medium 199 . Cells were counted on day 5 after plating. To test the effect of increasing amounts of exogenous fibronectin on endothelial cell proliferation, cluster 24-wells were coated overnight at room temperature with $600 \mu \mathrm{l}$ of $0.25,1,5,10$, or $50 \mu \mathrm{g} / \mathrm{ml}$ human fibronectin (New York Blood Center, New York, N. Y., USA) in sterile PBS. The amount of fibronectin absorbed to the dishes was determined from the direct measurement of the amount of absorbed ${ }^{125}$ I-labelled fibronectin (ICN Biomedicals, Inc., Irvine, Calif., USA) mixed in tracer amounts to cold fibronectin. The fibronectin solutions (or the plain PBS used for control wells) were aspirated, and HUVEC were plated at $1 \times 10^{4}$ cell/well. Cells were counted on day 2 and 5 after plating. To investigate the effect of elevated concentrations of fibronectin on cell cycle traversal, HUVEC seeded at $1 \times 10^{5}$ cells/dish in $35 \mathrm{~mm}$ dishes coated with $50 \mu \mathrm{g} / \mathrm{ml}$ fibronectin or uncoated were partially synchronized on day 2 after plating by reducing the amount of serum in the medium to $4 \%$ (complete serum withdrawal led to substantial cell detachment). After $48 \mathrm{~h}$ the cultures were returned to complete medium, and were harvested $48 \mathrm{~h}$ later to measure cell number and distribution along the cell cycle using flow cytometry $\left(\right.$ Kinesis $^{\mathrm{R}} 50$ reagents; BioRad, Richmond, Calif., USA).

A ttachment assay and N orthern analysis. To study the function and synthesis of integrins in cells grown on increasing concentrations of fibronectin, HUVEC cultured for 5 days in $60 \mathrm{~mm}$ tissue culture dishes coated with 1 or $10 \mu \mathrm{g} / \mathrm{ml}$ fibronectin, or uncoated, were tested for attachment properties and integrin mRNA levels. For the attachment assay, cells were released from the dishes by trypsinization and plated in 96-well microtitre plates coated overnight with fibronectin at $2.5 \mu \mathrm{g} / \mathrm{ml}$ and postcoated with bovine serum albumin (BSA) to block nonspecific binding. Attachment was tested after $30 \mathrm{~min}$ at $37^{\circ} \mathrm{C}$ as previously described [13]. Cultures companion to those providing cells for the attachment assay were simultaneously harvested for RNA extraction. Northern blots [14] were hybridized to ${ }^{32} \mathrm{P}$-labelled cDNAs for the human integrin $\alpha 5$ and $\beta 1$ subunits (fibronectin receptor $\alpha$ and $\beta$ chains, Gibco), and chicken $\beta$-actin (Oncor, Gaithersburg, Md., USA). The $\beta$-actin signal was used to control for RNA loading insofar as $\beta$-actin mRNA levels were not altered by growth on fibronectin $(89 \pm 26 \%$ of control in HUVEC cultured on $1 \mu \mathrm{g} / \mathrm{ml}$ fibronectin and $99 \pm 61$ of control in HUVEC cultured on $10 \mu \mathrm{g} / \mathrm{ml}$ fibronectin).

Fluorescence staining. The distribution of fibronectin, integrins, vinculin (a protein of focal adhesions), and F-actin was studied by fluorescence staining in HUVEC cultured for 3 days in $35 \mathrm{~mm}$ dishes coated with 1 or $50 \mu \mathrm{g} / \mathrm{ml}$ fibronectin, or uncoated. All procedures were performed at room temperature. Cells were washed with PBS, fixed with $10 \%$ buffered formalin for $10 \mathrm{~min}$, and permeabilized with $0.1 \%$ Triton X100 in PBS for $10 \mathrm{~min}$. After washing, non-specific binding was blocked with $1 \% \mathrm{BSA}$ in PBS for $30 \mathrm{~min}$. Circles of $0.4 \mathrm{~cm}$ diameter were scribed onto the dish, the cells outside the circles were wiped off with a cotton applicator, and the islands of cells were further delimited with a hydrophobic marker (PAP PEN; Polysciences, Inc., Warrington, Pa., USA). This procedure permitted morphological data to be obtained under culture conditions identical to those used in the proliferation, attachment, and mRNA studies; and to test several proteins in the same culture. Rabbit anti-human fibronectin antibodies (Sigma Chemical Co., St. Louis, Mo., USA) and mouse anti-human vinculin monoclonal antibodies (Sigma) were used at a dilution of 1:100; rat anti-human $\beta 1$ integrin monoclonal antibodies (gift of Dr. C.H.Damsky) were used at a dilution of 1:50. Antibodies were diluted in 1\% BSA in PBS and incubated with cells for $1 \mathrm{~h}$. After three washes in PBS, the appropriate fluorescein isothiocyanate (FITC)-conjugated secondary antibodies diluted 1:100 were added for $1 \mathrm{~h}$. F-actin was stained with rhodamine phalloidin (Molecular Probes Inc., Eugene, Ore., USA) using a 1:40 dilution of the $6.6 \mu \mathrm{mol} / 1$ stock solution for $1 \mathrm{~h}$ in the dark. After three final washes in PBS, the preparations were mounted in Slow Fade (Molecular Probes) and viewed under a Zeiss Axiophot fluorescence microscope. In negative controls the primary antibodies were omitted or substituted with non-immune serum. 
In selected experiments cells were double-stained for vinculin and F-actin.

$\mathrm{F}$-actin quantitation. To obtain quantitative data on the F-actin content of HUVEC plated on 1,10 , or $50 \mu \mathrm{g} / \mathrm{ml}$ fibronectin or tissue culture plastic, cells fixed, permeabilized, and stained with rhodamine phalloidin as described above, were treated with methanol for $1 \mathrm{~h}$ at $37^{\circ} \mathrm{C}$ in the dark. The extracted fluorescence was quantitated by fluorometry at excitation and emission settings of 550 and $580 \mathrm{~nm}$, respectively. The F-actin content was expressed as fluorescence units $/ 10^{6}$ cells.

Cytochalasin studies. To test the effect of increased cellular Factin content on proliferation, HUVEC seeded onto $50 \mu \mathrm{g} / \mathrm{ml}$ fibronectin or plastic (cluster 24 wells) at $5 \times 10^{4}$ cells/well were grown for 3 days in the presence or absence of cytochala$\sin \mathrm{D}$, a compound known to disrupt the actin filament component of cytoskeletal networks [15]. Cytochalasin D (Sigma) was added $4 \mathrm{~h}$ after seeding to allow for undisturbed cell attachment, at concentrations from 0.001 to $0.1 \mu \mathrm{g} / \mathrm{ml}$. A medium change was performed on day 2 , and cells were counted on day 3 . The effect of cytochalasin on cellular F-actin distribution was examined by fluorescence staining as described above.

Statistical analysis. Data are presented as mean \pm SD. Statistical analyses were by ANOVA followed by the Fisher multiple comparison procedure. The changes in integrin mRNA levels were analysed with the Wilcoxon signed-rank test.

\section{Results}

Excess endogenous or exogenous ECM impairs endothelial cell proliferation. To test the effect of excess endogenous ECM, HUVEC were plated on ECM prepared from cultures that had been exposed to high glucose concentrations $(30 \mathrm{mmol} / \mathrm{l})$ for 12 days. Under these conditions most HUVEC isolates manifest overexpression of fibronectin and collagen IV and increased deposition of the proteins into the matrix [12]. Four of the HUVEC isolates plated on the ECM deposited by cultures exposed to high glucose yielded a lower cell number than cells plated on control ECM (68 $\pm 18 \%$ of control) (Fig. 1). The fact that a decreased cell number was evident in four of the six isolates studied is compatible with our previous finding that overexpression of ECM components is detected in approximately $70 \%$ of the HUVEC isolates cultured in high glucose medium [12].

To assess the effects of excess ECM independent of possible post-translational modifications of its components induced by elevated glucose levels, HUVEC were cultured on increasing concentrations of exogenous fibronectin. Excess fibronectin is an abnormality relevant to diabetic vessels [16]. Because certain preparations of fibronectin have been reported to contain TGF- $\beta$ [17] which has growth inhibitory effects on endothelial cells, the TGF- $\beta$ content of the fibronectin preparation was tested by bioassay as previously described [18]. The largest concentration of fibronectin used $(50 \mu \mathrm{g} / \mathrm{ml})$ was found in two

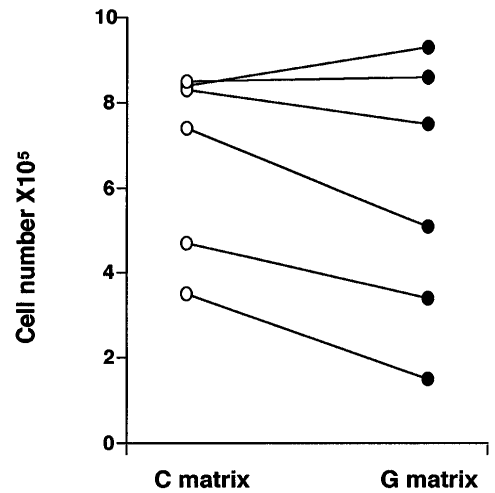

Fig. 1. Effect of matrix produced by HUVEC exposed to $30 \mathrm{mmol} / 1$ glucose on cell proliferation. Intact, cell-free matrix was isolated as described in Methods from six cultures exposed to $30 \mathrm{mmol} / \mathrm{l}$ glucose for 12 days and six paired control cultures exposed to $5 \mathrm{mmol} / \mathrm{l}$ glucose; control HUVEC were then plated onto the cell-free matrix and counted 5 days after plating. Each symbol represents the mean of counts in duplicate-triplicate dishes of an isolate originating from a single umbilical cord. The data from the same isolate plated on control (C) or high glucose $(\mathrm{G})$ matrix are connected by a line

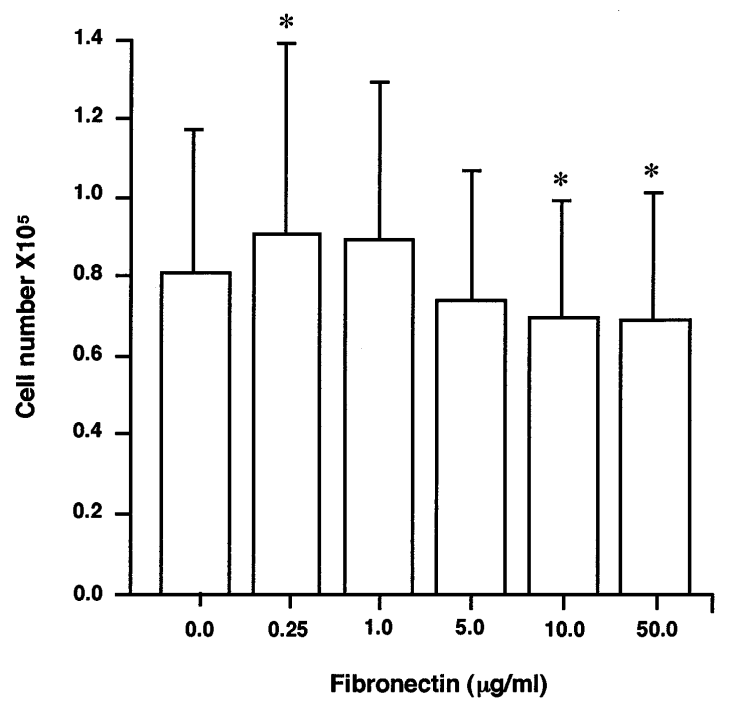

Fig. 2. Effect of increasing concentrations of fibronectin on HUVEC proliferation. Control cells $(0 \mu \mathrm{g} / \mathrm{ml}$ fibronectin $)$ were plated on tissue culture plastic. Bars denote mean \pm SD of cell counts obtained 5 days after plating in 9 individual HUVEC isolates. Cell counts were performed in duplicate-triplicate dishes. $* p<0.05$ vs control

experiments to contain 5.6 and $9.4 \mathrm{pg} / \mathrm{ml}$ mature TGF- $\beta$, respectively; concentrations that were devoid of any growth inhibitory effect on HUVEC proliferation. The fibronectin solutions used to coat the dishes $(0.25,1,5,10$, and $50 \mu \mathrm{g} / \mathrm{ml})$ resulted in the following amounts of deposited fibronectin (in $\mu \mathrm{g} / \mathrm{cm}^{2}, \mathrm{n}=3$ ): $0.06 \pm 0.01, \quad 0.27 \pm 0.01, \quad 0.83 \pm 0.1, \quad 1.24 \pm 0.2$, and $3.13 \pm 1.0$, respectively. A tendency to saturation of binding has been observed also by other investigators [6]. Immunofluorescence staining revealed that in the 


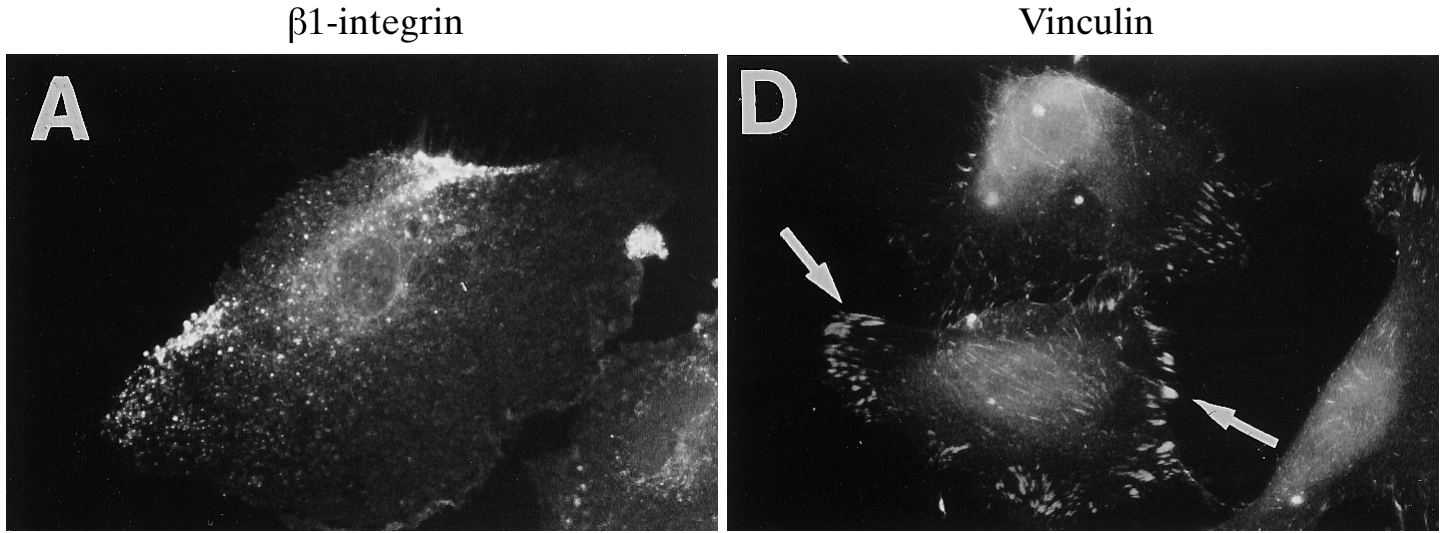

Plastic
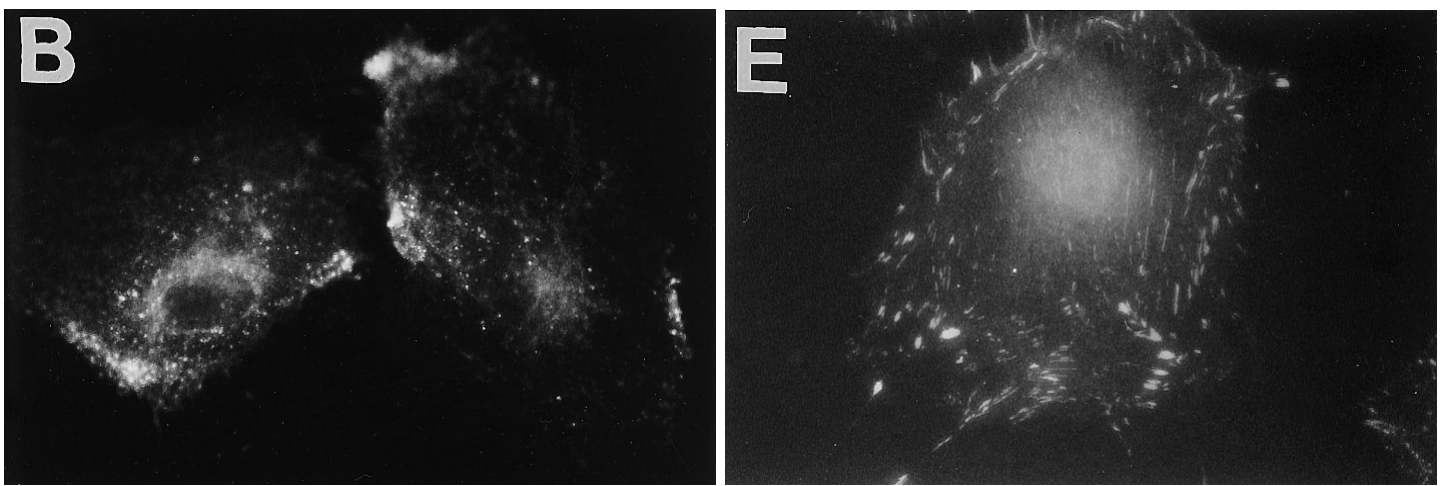

Fibronectin $1 \mu \mathrm{g} / \mathrm{ml}$
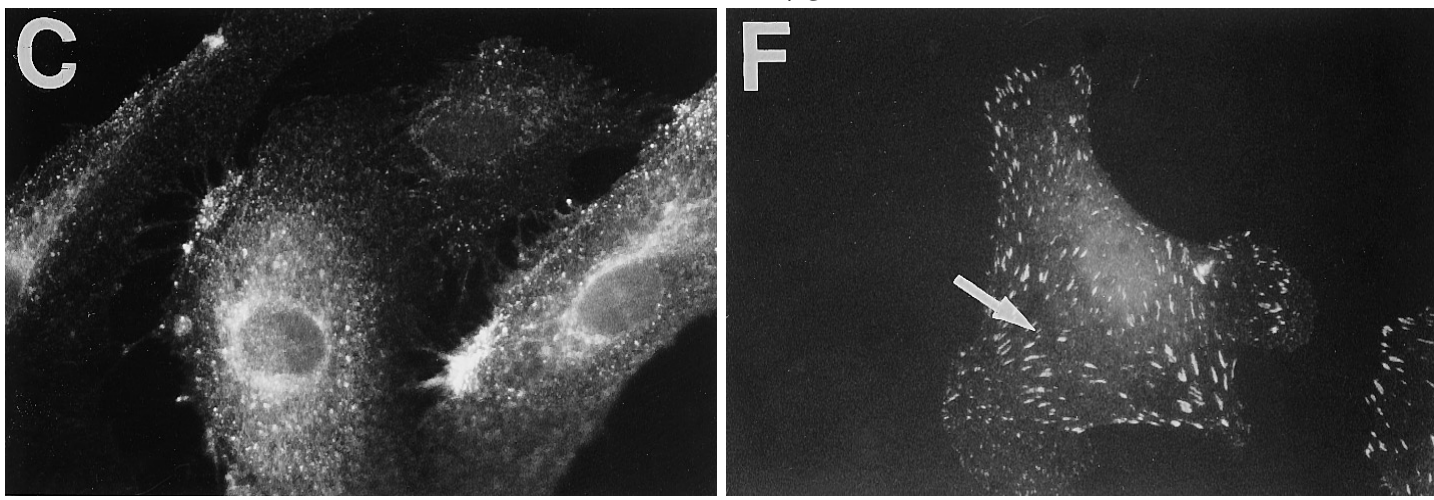

Fibronectin $50 \mu \mathrm{g} / \mathrm{ml}$

Fig. 3A -F. Distribution of $\beta 1$ integrin (A-C) and vinculin (D$F$ ) in HUVEC cultured on tissue culture plastic (A, D), $1 \mu \mathrm{g} / \mathrm{ml}$ fibronectin $(\mathrm{B}, \mathrm{E})$, or $50 \mu \mathrm{g} / \mathrm{ml}$ fibronectin $(\mathrm{C}, \mathrm{F})$, as detected by indirect immunofluorescence. Cells were examined 3 days after plating. Magnification $\times 1600$. Arrows in D and $E$ point to the peripheral localization of focal adhesion sites, in $\mathrm{F}$ to the increased number of adhesion sites present throughout the cell body

presence of cells the fibronectin coating became organized in a fibrillar network whose density increased in parallel with the concentrations of fibronectin, indicating that the glycoprotein was incorporated into the insoluble matrix. HUVEC cultured on the lowest concentration of fibronectin showed a modest increase in cell number when compared to control cultures plated on plastic, whereas on the larger concentrations $(10-50 \mu \mathrm{g} / \mathrm{ml})$ exhibited a decreased cell number. The trend was apparent on day 2 after plating and became highly significant ( $p=0.0001$ ) on day 5 (Fig. 2). Studies performed in cultures partially synchronized by reduction of the serum content of the medium and returned for $48 \mathrm{~h}$ to full medium showed that the cells plated on $50 \mu \mathrm{g} / \mathrm{ml}$ fibronectin had an altered distribution along the cell cycle. In these cultures the percent of cells in $\mathrm{G}_{\mathrm{o}}-\mathrm{G}_{1}$ was $58 \pm 4$ vs $48 \pm 3$ in control cultures plated on plastic, in $S$ phase was $24 \pm 6$ vs $37 \pm 5$ in control cultures, and in $\mathrm{G}_{2}-\mathrm{M}$ was $17 \pm 4$ vs $14 \pm 1$ in control cultures $(p<0.005)$. The pattern indicates delayed transit of cells plated on excess fibronectin along the $G_{1}$ phase of the cell cycle and into $\mathrm{S}$ phase. 

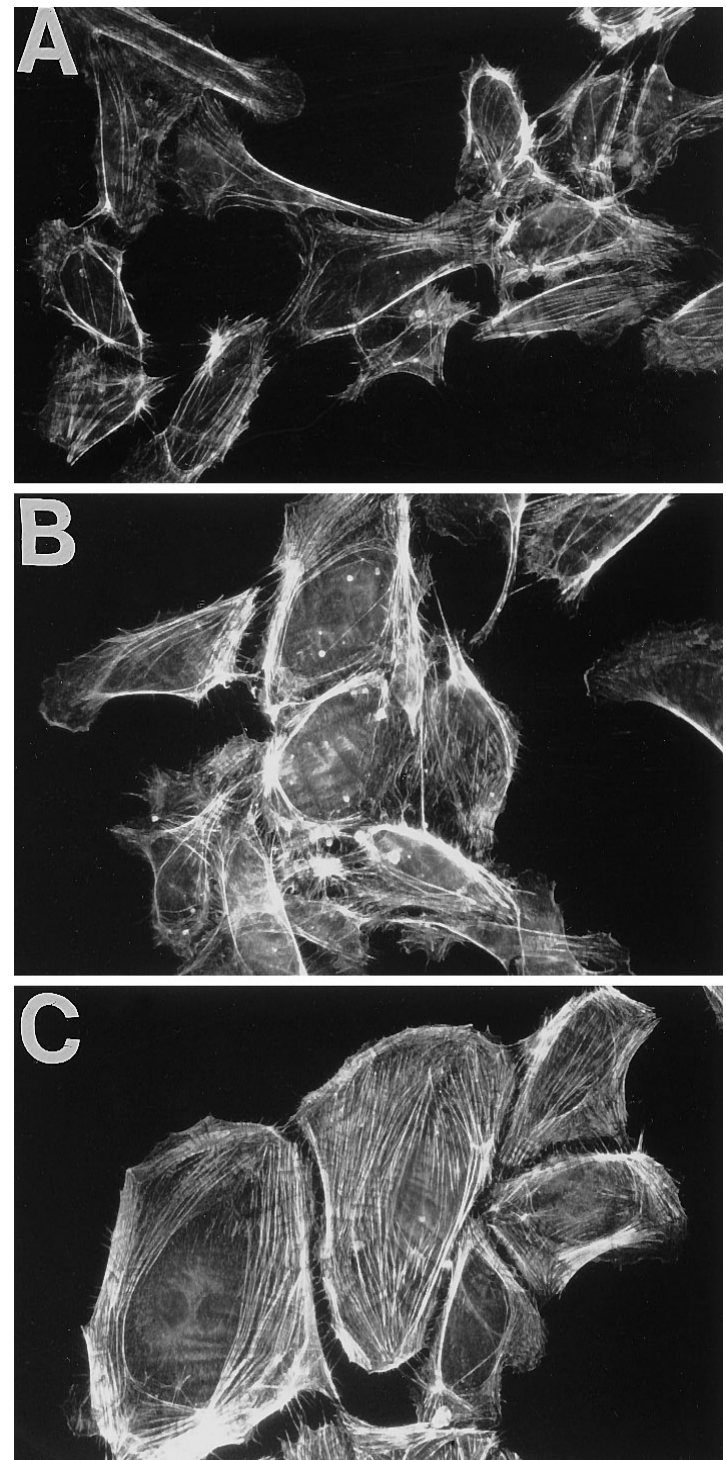

Fig. 4A - C. Distribution of F-actin in HUVEC cultured on tissue culture plastic (A), $1 \mu \mathrm{g} / \mathrm{ml}$ fibronectin (B), or $50 \mu \mathrm{g} / \mathrm{ml} \mathrm{fi-}$ bronectin (C). F-actin was stained with rhodamine phalloidin and viewed under the fluorescence microscope. Cells were examined 3 days after plating. Magnification $\times 800$

Excess fibronectin increases focal adhesion sites and actin polymerization. To identify molecular changes associated with the decreased proliferation on the larger concentrations of fibronectin, HUVEC plated on tissue culture plastic, $1 \mu \mathrm{g} / \mathrm{ml}$ fibronectin, and 10 or $50 \mu \mathrm{g} / \mathrm{ml}$ fibronectin were compared vis à vis the behaviour of proteins that link the ECM to the intracellular compartment [19]. Integrin function as measured in an attachment assay was increased in cells grown on both 1 and $10 \mu \mathrm{g} / \mathrm{ml}$ fibronectin (144 \pm 30 and $147 \pm 37 \%$ of control cells grown on plastic, respectively, $p<0.01)$. There was also a modest upregulation of the expression of the integrin subunits $\alpha 5$ and $\beta 1$, which combine to form a fibronectin-specific receptor. In cells grown on $1 \mu \mathrm{g} / \mathrm{ml}$ fibronectin the steady-state levels of $\alpha 5$ and $\beta 1$ mRNAs as measured by Northern analysis were $112 \pm 36 \%$ (NS) and $136 \pm 28 \%(p<0.05)$ of control, respectively; in cells grown on $10 \mu \mathrm{g} / \mathrm{ml}$ fibronectin $\alpha 5 \mathrm{mRNA}$ was increased to $140 \pm 56 \%$ of control $(p=0.05)$ and $\beta 1$ mRNA was $159 \pm 103 \%$ of control (NS). Previous studies in HUVEC have shown that changes in integrin subunits mRNAs are accompanied by changes in the level of the cognate proteins [13].

The integrin properties measured by the attachment assay and mRNA levels could not account for the growth-retarding effect of the large concentrations of fibronectin, insofar as the magnitude of changes was similar in cells plated on 1 or $10 \mu \mathrm{g} / \mathrm{ml} \mathrm{fi-}$ bronectin, but only the latter concentration resulted in decreased proliferation. Unique to the large concentrations of fibronectin however was the in situ distribution of $\beta 1$ integrin and of vinculin, a protein of focal adhesions (Fig.3). HUVEC plated on plastic or $1 \mu \mathrm{g} / \mathrm{ml}$ fibronectin showed for both proteins a mostly peripheral localization, whereas cells plated on $50 \mu \mathrm{g} /$ $\mathrm{ml}$ fibronectin showed in addition immunofluorescence staining throughout the cell body, indicating a greater number of focal adhesion sites. In keeping with the notion that these sites anchor actin filaments [19], the distribution and abundance of filamentous actin (F-actin) was found altered in cells grown on $50 \mu \mathrm{g} / \mathrm{ml}$ fibronectin (Fig. 4). HUVEC grown on plastic or $1 \mu \mathrm{g} / \mathrm{ml}$ fibronectin showed rims of bright fluorescence corresponding to the peripheral actin bundles, whereas in cells grown on $50 \mu \mathrm{g} / \mathrm{ml}$ fibronectin F-actin fluorescence was almost as intense at the cell periphery as in the coarse stress fibers traversing the cell body and oriented in the long axis of the cells. Many of these cells also showed larger size than cells plated on plastic or $1 \mu \mathrm{g} / \mathrm{ml}$ fibronectin. In cells stained for both vinculin and $\mathrm{F}$-actin, the termination of the actin filaments could readily be localized at the regions of focal adhesions. Cellular content of F-actin as determined by fluorometric quantitation of extracted fluorescence was not increased in HUVEC plated on $1 \mu \mathrm{g} / \mathrm{ml}$ fibronectin $(105 \pm 7 \%$ of control cells plated on tissue culture plastic), but was significantly increased in HUVEC plated on $10 \mu \mathrm{g} / \mathrm{ml} \mathrm{fi-}$ bronectin $(133 \pm 16 \%$ of control, $p<0.05)$, or $50 \mu \mathrm{g} /$ $\mathrm{ml}$ fibronectin $(146 \pm 8 \%$ of control, $\mathrm{p}<0.05)$.

Cytochalasin D normalizes actin polymerization and cell proliferation in HUVEC plated on excess fibronectin. The effect that the altered cell-substratum interactions and cytoskeletal rearrangements may have on cell proliferation was tested using cytochalasin D. Cytochalasin D was added at concentrations that are orders of magnitude lower than those reported to disrupt the actin network [15], and were meant to prevent excess actin polymerization and the attendant mechanical constraints. At a concentration of $0.01 \mu \mathrm{g} / \mathrm{ml}$, cytochalasin D only minimally 

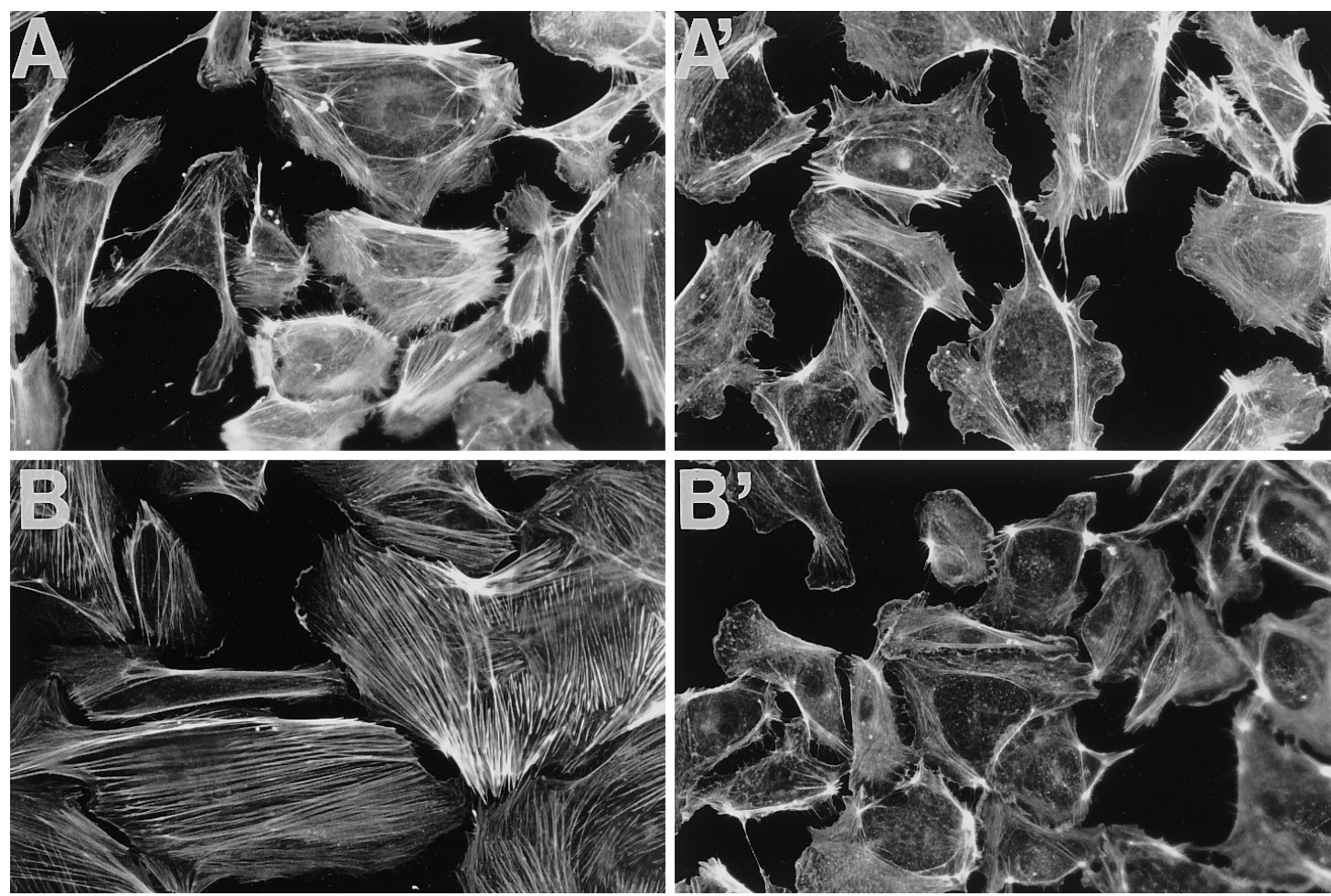

Fig. 5A , B. Effect of cytochalasin D on the distribution of Factin in HUVEC. Cells were plated on tissue culture plastic (A) or $50 \mu \mathrm{g} / \mathrm{ml}$ fibronectin (B), and exposed to cytochalasin $\mathrm{D}(0.01 \mu \mathrm{g} / \mathrm{ml})$ for 3 days $\left(\mathrm{A}^{\prime}\right.$ and $\left.\mathrm{B} '\right)$. Magnification $\times 800$

altered the size and shape of HUVEC grown on tissue culture plastic; stress fibers appeared slightly reduced and some cytoplasmic blebs appeared (Fig. 5A, A'). The same dose of cytochalasin D dramatically reduced the size of cells plated on $50 \mu \mathrm{g} / \mathrm{ml}$ fibronectin and the density of the stress fibers, returning morphology and cytoskeletal pattern to those observed in control cells plated on plastic (Fig. 5B, B'). Concomitantly with the structural changes, cytochalasin D at $0.01 \mu \mathrm{g} / \mathrm{ml}$ afforded correction of the replicative abnormality of cells grown on $50 \mu \mathrm{g} / \mathrm{ml}$ fibronectin, while not affecting the proliferation of control cells (Fig. 6). Lower doses $(0.001 \mu \mathrm{g} / \mathrm{ml})$ of cytochalasin $\mathrm{D}$ were not effective, and larger doses $(0.1 \mu \mathrm{g} / \mathrm{ml})$ prevented the proliferation of cells plated on plastic as well as on fibronectin (Fig.6).

\section{Discussion}

We have observed that vascular endothelial cells respond to large concentrations of fibronectin in vitro with a modest upregulation of integrin expression, striking redistribution of integrins and proteins of focal contacts to assemble in multiple clusters throughout the basal cytoplasm, increased actin polymerization and reorganization of the cytoskeleton to couple

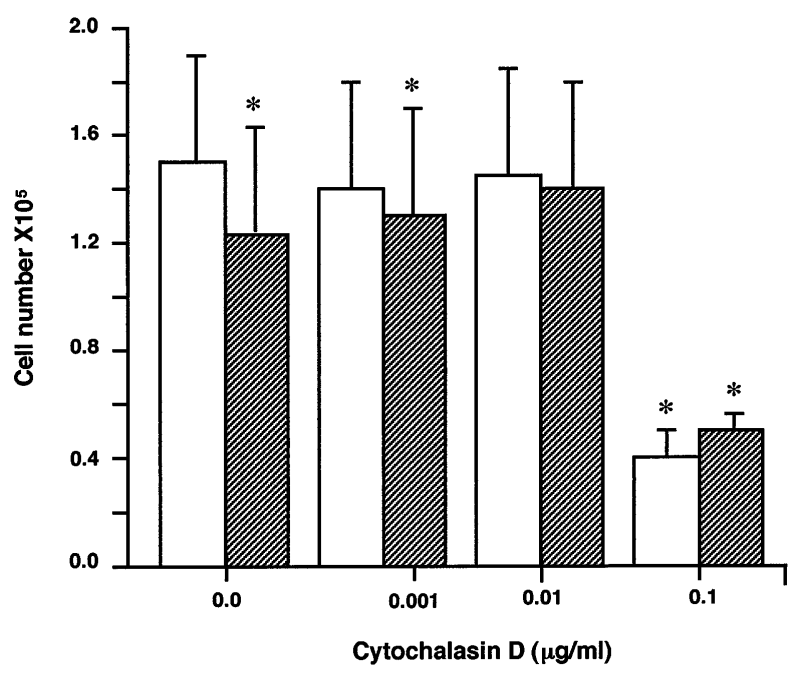

Fig. 6. Effect of cytochalasin D on the proliferation of HUVEC cultured on tissue culture plastic $(\square)$ or $50 \mu \mathrm{g} / \mathrm{ml}$ fibronectin $(\mathbb{Z})$. Bars denote the mean \pm SD of cell counts obtained 3 days after plating and initiation of the cytochalasin treatments in 10 individual HUVEC isolates. Cell counts were performed in duplicate-triplicate dishes. $* p<0.05$ vs control cells plated on plastic and not receiving cytochalasin treatment

actin filaments to the more numerous adhesion sites, and decreased replication. We have further observed that the increased actin polymerization is instrumental in causing the delayed replication.

The observations were made in cells plated on fibronectin, but there are reasons to believe that they describe a chain of events triggered by any ECM excess, since elements of the chain recur in multiple 
models. Endothelial cells cultured in the presence of high glucose concentrations upregulate the synthesis of several basement membrane components and relevant integrins, adhere more firmly to their matrix and show decreased replication $[12,13]$. In this study the ECM produced under high glucose conditions proved sufficient to reduce the replication of endothelial cells, in the absence of high ambient glucose. The inhibitory effects of TGF- $\beta$ on cell replication are attributable in some cell types to overproduction of collagen [20], are accompanied by reorganization of the actin cytoskeleton leading to thickened actin cables [21] and can be mimicked by the excess ECM produced in response to TGF- $\beta$ treatment [8]. Similarly, endothelial cells cultured in the presence of retinoids overproduce laminin and fibronectin, adhere more firmly to their substratum, and proliferate less than untreated cells [9]; the ECM produced by these cells results in decreased endothelial cell replication when compared with the ECM produced by untreated cells [9]. Overexpression of ECM components (especially fibronectin) during in vivo and in vitro aging of vascular endothelial cells and fibroblasts is coincidental with a decreased labelling index [22], and excessive ECM accumulation leading to altered topographical relationships of cells to their microenvironment has been cited as a mechanism for replicative senescence [23]. It is of note that excess complex matrix resulting from small increments in the synthesis of several components can have growth inhibitory effects of even greater magnitude $[8,9]$ than those afforded by the large concentrations of fibronectin used in this study. This suggests either that the multiple components contributing to the ECM excess exert additive or mutually potentiating effects, or that an excess of multiple components results in architectual modifications of the ECM especially likely to influence proliferation signals.

The facts that growth inhibition by excess fibronectin occurred in the $G_{1}$ phase of the cell cycle, was coincidental with an increased density of cellmatrix contacts, and was abolished by prevention of the attendant cytoskeletal reorganization, point to an interference with molecules that transduce mitogenic signals from adhesion sites. An appealing candidate is the $\mathrm{Na}^{+} / \mathrm{H}^{+}$antiporter, whose activation has a permissive role in the proliferative response to growth factors [24], and which localizes at sites of accumulation of vinculin, talin, and F-actin [25]. It is conceivable that the extent or nature of physical interactions of the $\mathrm{Na}^{+} / \mathrm{H}^{+}$antiporter with structural elements of the cytoskeleton governs antiporter activity, and thus the responsiveness of cells to mitogenic stimulation. We have observed both in HUVEC exposed to high glucose and overexpressing fibronectin and in HUVEC cultured on excess fibronectin that decreased replication is accompanied by decreased activity of the $\mathrm{N}^{+} / \mathrm{H}^{+}$antiporter $[26$, 27]. Other investigators have reported similar results
- decreased proliferation and decreased antiporter activity - for kidney cells plated on increasing concentrations of type IV collagen [28]. These studies however do not establish causal relationships, and cannot exclude that the function of one or more of the other numerous molecules that generate signals at focal adhesions [29] may be modulated by quantitative changes in the ECM.

The in vitro observations reported here may have relevance to the vascular pathology of diabetes. Fibronectin synthesis is increased in the retina of diabetic patients with background retinopathy, and the retinal microvessels of these patients show increased fibronectin immunostaining when compared with vessels of non-diabetic control subjects [16]. Especially if vascular endothelial cell turnover is accelerated by the occurrence of cell death in diabetes [11], excess deposition of fibronectin and/or other ECM components may become, through the hampering effect on endothelial cell replication, important contributors to the microvascular obliteration that leads to retinal ischaemia and sight-threatening neovascularization. Strategies are now being devised to test the prediction in vivo.

A cknowledgements. The authors thank Dr. C.H. Damsky for providing the AIIB2 monoclonal antibodies. This work was supported by grant EY09122 from the National Institutes of Health, grant \# 193153 from the Juvenile Diabetes Foundation International, the George and Frances Levin Endowment, and a donation from Mrs Jane Beck. Dr. Podestá was the recipient of a postdoctoral fellowship from the Juvenile Diabetes Foundation International.

\section{References}

1. von der Mark K, von der Mark H, Goodman S (1992) Cellular responses to extracellular matrix. Kidney Int 41: 632-640

2. Streuli CH, Schmidhauser C, Bailey N et al. (1995) Laminin mediates tissue-specific gene expression in mammary epithelia. J Cell Biol 129: 591-603

3. Woodley DT, O'Keefe EJ, Prunieras M (1985) Cutaneous wound healing: a model for cell-matrix interactions. J Am Acad Dermatol 12: 420-433

4. Lorenzi M, Cagliero E (1991) Pathobiology of endothelial and other vascular cells in diabetes mellitus. Call for data. Diabetes 40: 653-659

5. Steffes MW, Østerby R, Chavers B, Mauer SM (1989) Mesangial expansion as a central mechanism for loss of kidney function in diabetic patients. Diabetes 38: 1077-1081

6. DiMilla PA, Stone JA, Quinn JA, Albelda SM, Lauffenburger DA (1993) Maximal migration of human smooth muscle cells on fibronectin and type IV collagen occurs at an intermediate attachment strength. J Cell Biol 122: 729737

7. Madri JA, Pratt BM, Yannariello-Brown J (1988) Matrixdriven cell size change modulates aortic endothelial cell proliferation and sheet migration. Am J Pathol 132: 18-27

8. Newton LK, Yung WKA, Cree Pettigrew L, Steck PA (1990) Growth regulatory activities of endothelial extracellular matrix: mediation by transforming growth factor- $\beta$. Exp Cell Res 190: 127-132 
9. Paige K, Palomares M, D'Amore PA, Braunhut SJ (1991) Retinol-induced modifications of the extracellular matrix of endothelial cells: its role in growth control. In Vitro Cell Dev Biol 27A:151-157

10. Engerman RL, Pfaffenbach D, Davis MD (1967) Cell turnover of capillaries. Lab Invest 17: 738-743

11. Mizutani M, Kern TS, Lorenzi M (1996) Accelerated death of retinal microvascular cells in human and experimental diabetic retinopathy. J Clin Invest 97: 2883-2890

12. Cagliero E, Roth T, Roy S, Lorenzi M (1991) Characteristics and mechanisms of high glucose-induced overexpression of basement membrane components in cultured human endothelial cells. Diabetes 40: 102-110

13. Roth T, Podestá F, Stepp MA, Boeri D, Lorenzi M (1993) Integrin overexpression induced by high glucose and by human diabetes: potential pathway to cell dysfunction in diabetic microangiopathy. Proc Natl Acad Sci USA 90: 9640 9644

14. Cagliero E, Maiello M, Boeri D, Roy S, Lorenzi M (1988) Increased expression of basement membrane components in human endothelial cells cultured in high glucose. J Clin Invest 82: 735-738

15. Schliwa M (1982) Action of cytochalasin D on cytoskeletal networks. J Cell Biol 92: 79-91

16. Roy S, Cagliero E, Lorenzi M (1996) Fibronectin overexpression in retinal microvessels of patients with diabetes. Invest Ophthalmol Vis Sci 37: 258-266

17. Fava RA, McClure DB (1987) Fibronectin-associated transforming growth factor. J Cell Physiol 131: 184-189

18. Cagliero E, Roth T, Taylor AW, Lorenzi M (1995) The effects of high glucose on human endothelial cell growth and gene expression are not mediated by transforming growth factor- $\beta$. Lab Invest 73: 667-673

19. Burridge K, Fath K, Kelly T, Nuckolls G, Turner C (1988) Focal adhesions: transmembrane junctions between the extracellular matrix and the cytoskeleton. Ann Rev Cell Biol 4: 487-525

20. Nugent MA, Newman MJ (1989) Inhibition of normal rat kidney cell growth by transforming growth factor- $\beta$ is mediated by collagen. J Biol Chem 264: 18060-18067

21. Segarini PR, Rosen DM, Seyedin SM (1989) Binding of transforming growth factor-b to cell surface proteins varies with cell type. Mol Endocrinol 3: 261-272

22. Kumazaki T, Kobayashi M, Mitsui Y (1993) Enhanced expression of fibronectin during in vivo cellular aging of human vascular endothelial cells and skin fibroblasts. Exp Cell Res 205: 396-402

23. Goldstein S (1990) Replicative senescence: the human fibroblast comes of age. Science 249: 1129-1133

24. Grinstein S, Rotin D, Mason MJ (1989) $\mathrm{Na}^{+} / \mathrm{H}^{+}$exchange and growth factor-induced cytosolic $\mathrm{pH}$ changes. Role in cellular proliferation. Biochim Biophys Acta 988: 73-97

25. Grinstein S, Woodside M, Waddell TK et al. (1993) Focal localization of the NHE-1 isoform of the $\mathrm{Na}^{+} / \mathrm{H}^{+}$antiporter: assessment of effects on intracellular $\mathrm{pH}$. EMBO J 12: 5209-5218

26. Zerbini G, Roth T, Podestá F et al. (1995) Activity and expression of the $\mathrm{Na}^{+} / \mathrm{H}^{+}$exchanger in human endothelial cells cultured in high glucose. Diabetologia 38: 785-791

27. Podestá F, Zerbini G, Gabellini D, Mangili R, Pozza G (1995) Activity of the $\mathrm{Na}^{+} / \mathrm{H}^{+}$exchanger in human endothelial cells cultured on high concentrations of fibronectin. J Am Soc Nephrol 6: 907 (Abstract)

28. Green J, Foellmer O, Kleeman CR (1994) Collagen type 4 substratum (coll-4) inhibits the $\mathrm{Na}^{+} / \mathrm{H}^{+}$exchanger (NHE) in OKP cells. J Am Soc Nephrol 5: 254 (Abstract)

29. Clark EA, Brugge JS (1995) Integrins and signal transduction pathways: the road taken. Science 268: 233-239 